\title{
DESCRIPTION OF THE YELLOW-FINNED TROUT OF TWIN LAKES, COLORADO.*
}

\author{
BY \\ David Starr Jordan and Barton Warren Evermann.
}

Salmo mykiss macdonaldi subsp. nov.

Type No. 41730, U. S. Natignal Museum.

Head, 4 to $4_{10}^{1}$ in length ; depth, $4 \frac{1}{6}$ to 5 ; D. 2, 12 . A. 1, 11. B. 10, Scales, 40-184-37, about 125 pores. Length of type, 10 inches; other specimens from 5 to 8 inches.

Body more elongate and more compressed than usual among the trout; head long, compressed, the snout moderately pointed; mouth rather large, the jaws subequal, the maxillary extending beyond the eye, $1 \frac{3}{4}$ to 2 in head; hyoid teeth present, small; opercle longer than usual, its greatest length $4 \frac{1}{3}$ in head, somewhat greater than eye, its posterior margin strongly convex. Eye $5_{3}^{1}$ in head; snout $4 \frac{1}{8}$; gill rakers short, $\mathrm{x}+10$.

Scales quite small, and regularly piaced. Pectoral fin moderate, $1 \frac{2}{3}$ in head; ventrals 2 . Caudal moderately emarginate, the lobes equal. $1 \frac{2}{3}$ in head.

Color silvery-olive, a broad lemon-yellow shade along the sides; lower fins bright golden yellow in life; no trace of red, except the usual crimson dash under the lower jaw, never wanting in Salmo mykiss.

Body posteriorly and on dorsal and caudal fin profusely speckled with small pepper-like spots, smaller than the nostril, and smaller than in any other of the forms of Salmo mykiss. Occasionally these spots are numerous on the anterior part of the body, and even on the head, but usually they are very sparse before the dorsal fin. A round dark diffuse blotch on cheek behind eye.

Pyloric ceeca about 40.

Stomach containing some vegetable matter, bones of suckers, and what appears to be a very large flat white worm, apparently swallowed as part of its food.

About ten specimens of this species were taken with the fly in the lower Twin Lakes, about 15 miles southwest of Leadville, a beautiful mountain lake tributary to the Arkansas River.

Most of the specimens were taken by Mr. George R. Fisher, of Leadville, a very enthusiastic and very well informed angler who first made 
known to us the existence of the species, and accompanied our trip in seareh of it.

There are two kinds of trout native to this lake, the yellow-fin or "Salmon Trout," above described, and the smaller "Greenback Trout," also found in the Arkansas and Platte, Salmo mykiss stomias.

The yellow-fin trout lires largely on the gravels and about the north or sunny side of the lake. It reaches a weight of 7 to 10 pounds, the very large fish being usually taken with the spear; specimens of 13 pounds' weight are reported. The species never leaves the lake except to spawn, and most of them spawn in the lake. It has never been seen in the river, and rarely in very deep water.

This fish feeds freely on young suckers and even on young trout. It spawns in spring, and the suckers infest its spawning beds, devouring the eggs.

The flesh of the yellow-fin trout is very pale, and more watery than that of the other trout of Colorado. In flaror, its flesh is not inferior to the other species. The color of the flesh may be due to the fact that it feeds on fishes rather than on crustacea. The "Greenback Trout" (S. m. stomias) feeds on crustacea and has very red flesh.

We have taken pleasure in naming this species for Hon. Marshall MeDonald, U. S. Commissioner of Fisheries, in recognition of his services in spreading the range of Salmonida in America.

University of Indiana, January 10, 1890. 


\section{$2 \mathrm{BHL}$ Biodiversity Heritage Library}

Jordan, David Starr and Evermann, Barton Warren. 1890. "Description of the yellow-finned trout of Twin Lakes, Colorado." Proceedings of the United States National Museum 12(780), 453-454.

https://doi.org/10.5479/si.00963801.12-780.453.

View This Item Online: $\underline{\text { https://www.biodiversitylibrary.org/item/53609 }}$

DOI: https://doi.org/10.5479/si.00963801.12-780.453

Permalink: https://www.biodiversitylibrary.org/partpdf/52725

\section{Holding Institution}

Smithsonian Libraries

\section{Sponsored by}

Smithsonian

\section{Copyright \& Reuse}

Copyright Status: Public domain. The BHL considers that this work is no longer under copyright protection.

This document was created from content at the Biodiversity Heritage Library, the world's largest open access digital library for biodiversity literature and archives. Visit BHL at https://www.biodiversitylibrary.org. 